\section{Comparison of serum creatinine levels in different color/race categories in a Brazilian population}

\author{
Comparação dos níveis séricos da creatinina entre \\ diferentes categorias de raça/cor em \\ uma população brasileira
}

\section{Comparación de los niveles séricos de la creatinina entre diferentes categorías de raza/color en una población brasileña}

Roberto Carlos de Brito Barcellos 1 Jorge Paulo Strogoff de Matos 1 Hye Chung Kang 1 Maria Luiza Garcia Rosa 1 Jocemir Ronaldo Lugon 1

\author{
1 Universidade Federal \\ Fluminense, Niterói, Brasil. \\ Correspondence \\ R. C. B. Barcellos \\ Universidade Federal \\ Fluminense. \\ Rua Marquês do Paraná 303 \\ Niterói, $R J$ \\ 24033-900, Brasil. \\ rcb.barcellos@gmail.com
}

\begin{abstract}
Serum creatinine ( $\mathrm{SCr}$ ) is usually higher among black people in the United States due to increased muscle mass, justifying the addition of race adjustment in creatinine-based formulas to estimate glomerular filtration rate (eGFR). We aimed to assess if $\mathrm{sCr}$ levels are different in low-income communities in Brazil according to their race. A total of 1,303 participants were enrolled (58\% fe-

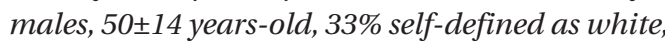
$41 \%$ as mixed race, and $26 \%$ as black). No significant differences in $\mathrm{s} C \mathrm{r}$ were found between racial groups and no influence of race on $\mathrm{sCr}$ was seen in the linear regression analysis. The eGFR, calculated using the Chronic Kidney Disease Epidemiology Collaboration (CKD-EPI) formula with no race adjustment, was no different between whites, mixed race and blacks. However, using such adjustment, eGFR for mixed race and black individuals was significantly higher than for whites ( $p<$ 0.001). In conclusion, no significant differences in $s$ Cr levels were found between racial groups, raising doubts as to whether race adjustment in eGFR formula should be used in that population.

Creatinine; Glomerular Filtration Rate; Ethnicity and Health
\end{abstract}

\section{Resumo}

A creatinina (Cr) sérica é geralmente mais elevada entre os negros nos Estados Unidos devido ao aumento da massa muscular, o que justificaria o ajuste pela raça nas fórmulas derivadas da Cr para calcular a taxa de filtração glomerular estimada (TFGe). Nosso objetivo foi avaliar se os níveis de Cr são diferentes entre as raças em comunidades de baixa renda no Brasil. Um total de 1.303 participantes foi incluído na análise (58\% mulheres, $50 \pm 14$ anos, 33\% autoclassificados como brancos, $41 \%$ como pardos e $26 \%$ como negros). Não foram encontradas diferenças significativas na Cr entre grupos raciais e nenhuma influência da raça sobre a Cr foi vista na análise de regressão linear. TFGe usando-se a fórmula da Chronic Kidney Disease Epidemiology Collaboration (CKD-EPI) sem ajuste por raça não foi diferente entre brancos, pardos e negros. No entanto, usando-se esse ajuste, a TFGe para pardos e negros foi mais elevada do que para os brancos ( $p<0,001)$. Concluindo, não foram encontradas diferenças significativas nos niveis de Cr entre os grupos raciais, levantando dúvidas se o ajuste por raça na fórmula para TFGe deva ser usado nessa população.

Creatinina; Taxa de Filtração Glomerular; Origem Étnica e Saúde 


\section{Introduction}

Chronic kidney disease (CKD) is currently recognized as a major burden for the global public health system. Early detection and treatment of CKD using readily available, inexpensive therapies can slow or prevent progression to end-stage renal disease 1,2 . The use of formulas, based on serum creatinine levels, in order to estimate the glomerular filtration rate (eGFR) is widely accepted ${ }^{3}$. The development of such formulas was derived from large clinical trials in which GFR was measured by gold-standard methods. Firstly, the modification of diet in renal disease (MDRD) formula ${ }^{4}$ was developed based on a sample of CKD patients, and later, the Chronic Kidney Disease Epidemiology Collaboration (CKD-EPI) formula 5 was derived from a pooled data of clinical studies, representative of the U.S. adult population. For both formulas, the strongest correlations between directly measured GFR and the estimated values were achieved after adjustment for age, sex and race (black or non-black). Serum creatinine levels are dependent not only on GFR, but also on body muscle mass, which are reduced in females and elderly people 6 . Whether an adjustment for race is necessary for individuals with African heritage from other countries deserves further investigation. Thus, the aim of the present study was to assess if serum creatinine levels are higher among black and mixed race individuals compared with white people in a low-income Brazilian population.

\section{Methods}

This is a cross-sectional, observational study using the database of two studies (CAMELIA and DIGITALIS) conducted in a partnership between the Federal Fluminense University and the Niterói Healthcare Foundation. The population enrolled in the study was a low socio-economic, community-based health assisted program in the city of Niterói, Rio de Janeiro State, Brazil. Briefly, CAMELIA Study enrolled subjects over the age of 20, whereas participants in the DIGITALIS Study were older than 45 . In both studies, subjects were interviewed by trained researchers using a standardized questionnaire which included a selfdefined race or skin color categorization. The race was based on the Brazilian Institute of Geography and Statistics (IBGE; http://www.ibge. gov.br, accessed on 30/Jul/2012) classification and defined into three principal race or skin color groups: white, mixed race and black subjects.

Serum creatinine was measured using the chemistry analyzer Selectra (Vital Scientific NE,
Netherlands) for all patients in the CAMELIA Study, whereas the Cobas 8,000 analyzer C702 modular (Roche-Hitachi, Japan), calibrated to an isotope dilution mass spectrometry reference, was used for all participants of the DIGITALIS Study. GFR was estimated using the CKD-EPI formula with and without race adjustment.

Both protocols were approved by the ethics committee of the Antonio Pedro University Hospital (CAMELIA Study protocol number 220/05 and DIGITALIS Study protocol number 012/10), and participants gave written informed consent.

Results were expressed as mean \pm standard deviation or frequencies as appropriate. Student's t-test, ANOVA with Bonferroni post-hoc test and Kruskal-Wallis with Dunn post-hoc test were applied for comparison of means; chi-square test or Fisher's exact test for categorical variables. A linear regression model was used to determine the effects of age, sex and race on serum creatinine levels. Statistical significance was assumed if $p$ values were less than 0.05 . All statistical analyses were performed using SPSS, version 18.0 (IBM Corp., Armonk, USA).

\section{Results}

A total of 1,303 adults were included in this cross-sectional analysis. General characteristics of the studied population are presented in Table 1. Thirty-three percent of individuals were selfcategorized as white, $41 \%$ as mixed race and $26 \%$ as black. No other race/color was identified. No significant differences regarding demographics, blood pressure or laboratory variables, among white, mixed race and black individuals were found. Serum creatinine levels were not significantly different between white, mixed race and black subjects $(0.87 \pm 0.24 \mathrm{mg} / \mathrm{dL}, 0.87 \pm 0.20 \mathrm{mg} /$ $\mathrm{dL}, 0.90 \pm 0.33 \mathrm{mg} / \mathrm{dL}$, respectively).

Males had higher serum creatinine levels than females $(1.01 \pm 0.29 \mathrm{mg} / \mathrm{dL}$ vs. $0.78 \pm 0.17 \mathrm{mg} /$ $\mathrm{dL}, \mathrm{p}<0.001)$. Serum creatinine values stratified by sex, race and age ranges are depicted in $\mathrm{Ta}-$ ble 2. Differences in serum creatinine levels between racial groups were not found inside each sex group, except for elderly black females when compared with elderly mixed race females.

The linear regression analysis showed that the serum creatinine level was influenced by sex and age, but not by race (Table 3 ).

We calculated eGFR for the three racial groups with and without the proposed adjustment for race. Using the CKD-EPI formula without adjustment for race, the eGFR was not different between white, mixed race and black subjects $\left(88.6 \pm 20.8 \mathrm{~mL} / \mathrm{min} / 1.73 \mathrm{~m}^{2}\right.$ body sur- 
Table 1

General features of the participants by race.

\begin{tabular}{lcccc}
\hline & $\begin{array}{c}\text { All } \\
(\mathbf{N}=\mathbf{1 , 3 0 3})\end{array}$ & $\begin{array}{c}\text { White } \\
(\mathbf{n}=\mathbf{4 3 3})\end{array}$ & $\begin{array}{c}\text { Mixed race } \\
(\mathbf{n}=\mathbf{5 3 5})\end{array}$ & $\begin{array}{c}\text { Black } \\
(\mathbf{n}=\mathbf{3 3 5})\end{array}$ \\
\hline Age (years) & $50.1 \pm 14.28$ & $52.0 \pm 15.2$ & $49.0 \pm 13.4$ & $49.6 \pm 14.2$ \\
Sex (\% males) & 42.0 & 42.5 & 47.3 & 36.1 \\
Systolic BP (mmHg) & $136 \pm 22$ & $135 \pm 21$ & $134 \pm 22$ & $139 \pm 23$ \\
Diastolic BP (mmHg) & $82 \pm 12$ & $81 \pm 12$ & $81 \pm 12$ & $84 \pm 12$ \\
Body mass index (Kg/m2) & $27.5 \pm 5.4$ & $27.3 \pm 5.2$ & $27.7 \pm 5.7$ & $27.6 \pm 5.5$ \\
Hemoglobin (g/dL) & $13.7 \pm 1.5$ & $13.8 \pm 1.5$ & $13.8 \pm 1.5$ & $13.4 \pm 1.5$ \\
Urea (mg/dL) & $31 \pm 11$ & $32 \pm 11$ & $30 \pm 9$ & $31 \pm 13$ \\
Serum creatinine $(\mathrm{mg} / \mathrm{dL})$ & $0.88 \pm 0.26$ & $0.87 \pm 0.24$ & $0.87 \pm 0.20$ & $0.90 \pm 0.33$ \\
U Alb/Cr (mg/g) & $7(4-15)$ & $8(5-16)$ & $6(4-14)$ & $7(4-15)$ \\
Microalbuminuria (\%) & 11.8 & 12.7 & 10.8 & 14.6 \\
Macroalbuminuria (\%) & 1.6 & 1.6 & 1.5 & 1.8 \\
\hline
\end{tabular}

BP: blood pressure; U Alb/Cr: urinary albumin/creatinine ratio.

Note: values are expressed as mean \pm standard deviation and median + interquartile.

Table 2

Serum creatinine levels $(\mathrm{mg} / \mathrm{dL})$ stratified according to sex, race and age ranges.

\begin{tabular}{|c|c|c|c|c|c|c|}
\hline \multirow[t]{2}{*}{ Age (years) } & \multicolumn{3}{|c|}{ Females } & \multicolumn{3}{|c|}{ Males } \\
\hline & $\begin{array}{l}\text { White } \\
(n=254)\end{array}$ & $\begin{array}{l}\text { Mixed race } \\
(n=287)\end{array}$ & $\begin{array}{c}\text { Black } \\
(n=214)\end{array}$ & $\begin{array}{l}\text { White } \\
(n=179)\end{array}$ & $\begin{array}{l}\text { Mixed race } \\
(n=248)\end{array}$ & $\begin{array}{c}\text { Black } \\
(n=121)\end{array}$ \\
\hline $20-39$ & $0.76 \pm 0.14$ & $0.74 \pm 0.14$ & $0.77 \pm 0.15$ & $1.0 \pm 0.15$ * & $0.97 \pm 0.18$ * & $0.97 \pm 0.18$ * \\
\hline 40-59 & $0.75 \pm 0.13$ & $0.76 \pm 0.15$ & $0.78 \pm 0.15$ & $0.97 \pm 0.19$ * & $0.97 \pm 0.18$ * & $1.05 \pm 0.52$ * \\
\hline$>60$ & $0.83 \pm 0.23$ & $0.83 \pm 0.18$ & $0.93 \pm 0.26$ ** & $1.14 \pm 0.45$ * & $1.08 \pm 0.25$ * & $1.17 \pm 0.29$ * \\
\hline All & $0.78 \pm 0.17$ & $0.78 \pm 0.16$ & $0.81 \pm 0.19$ & $1.02 \pm 0.27$ * & $0.99 \pm 0.19$ * & $1.07 \pm 0.44$ * \\
\hline
\end{tabular}

${ }^{*} p<0.05$ males vs. females in the same age range;

** $p<0.05$ vs. mixed race females.

Note: values are expressed as mean \pm standard deviation.

Table 3

Association between variables and serum creatinine levels in the linear regression analysis.

\begin{tabular}{lcc}
\hline Variable & $\boldsymbol{\beta}$ coefficient $(95 \% \mathrm{Cl})$ & p-value \\
\hline Age (decade) & $0.035(0.026 ; 0.043)$ & $<0.001$ \\
Sex (male) & $0.222(0.197 ; 0.248)$ & $<0.001$ \\
Race (non-white) & $0.09(-0.05 ; 0.22)$ & 0.201 \\
\hline
\end{tabular}

95\% Cl: $95 \%$ confidence interval. 
face area [BSA], $90.6 \pm 19.5 \mathrm{~mL} / \mathrm{min} / 1.73 \mathrm{~m}^{2} \mathrm{BSA}$ and $87.1 \pm 20.5 \mathrm{~mL} / \mathrm{min} / 1.73 \mathrm{~m}^{2} \mathrm{BSA}$, respectively). However, it would be significantly higher for mixed race and blacks if a race adjustment were adopted $\left(109.6 \pm 22.5 \mathrm{~mL} / \mathrm{min} / 1.73 \mathrm{~m}^{2} \mathrm{BSA}\right.$ and $107.8 \pm 24.8 \mathrm{~mL} / \mathrm{min} / 1.73 \mathrm{~m}^{2} \mathrm{BSA}$, respectively; $\mathrm{p}<0.001$ vs. whites for both groups).

\section{Discussion}

The incorporation of creatinine-based formulas to estimate GFR has been helpful in the diagnosis and classification of CKD 7,8. The adjustment for race using the worldwide accepted MDRD and CKD-EPI formulas increases the eGFR in black people by $21 \%$ and $16 \%$, respectively. The higher eGFR for African-Americans at a given serum creatinine level is consistent with their greater skeletal muscle mass 9,10. However, it remains unknown if differences in skeletal muscle mass according to race are present in Brazil. Our findings suggest that the inclusion of race adjustment in the estimation of GFR does not seem appropriate in the studied Brazilian population. We found no differences in serum creatinine between white, mixed race and black people in a Brazilian community, even after stratification by sex and age. A small difference, with limited clinical relevance, was seen between mixed race and black females.
The race adjustment to estimate GFR has been validated for the United States population, in which people of African heritage are known to have higher serum creatinine than the other racial groups 9 . However, several authors outside the United States observed no need to apply race adjustments 11,12 .

Even if race has any effect on serum creatinine, we believe that the intense biological miscegenation 13 could attenuate the differences in the mean serum creatinine levels among white, mixed race and black people in our study.

Our study presents some limitations. The race classification was strictly based on self-definition and no genetic analysis was performed. Finally, we studied a sample of a specific community that may not be representative of the whole Brazilian population. Thus, our findings are valid only for the sampled population. A comprehensive Brazilian epidemiological study, including the assessment of kidney function is desirable in order to stablish if the use of race adjustment for estimation of GFR in creatinine-derived formulas is unnecessary in the Brazilian population.

In conclusion, our findings showed no difference as to serum creatinine levels between white, mixed race and black people. Therefore, the adjustment for race when estimating GFR in a low-income Brazilian population seems inappropriate.

\section{Resumen}

La creatinina (Cr) sérica es generalmente mayor entre los negros en los Estados Unidos debido al aumento de la masa muscular, lo que justificaría el ajuste por raza en las fórmulas derivadas de la Cr para estimar la tasa de filtración glomerular estimada (TFGe). Nuestro objetivo fue evaluar si los niveles de creatinina son diferentes entre las razas en las comunidades de bajos ingresos en Brasil. Un total de 1.303 participantes fueron

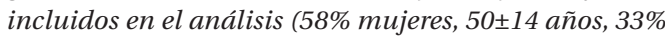
se clasificaron como blancos, $41 \%$ como pardos y $26 \%$ como negros). No hubo diferencias significativas en $\mathrm{Cr}$ entre los grupos raciales y no se observó influencia de la raza sobre la Cr en el análisis de regresión lineal. TFGe mediante la fórmula de la Chronic Kidney Disease Epidemiology Collaboration (CKD-EPI) sin ajustar para la raza no fue diferente entre brancos, pardos y negros. Sin embargo, con el uso del ajuste, la TFGe para los pardos $y$ negros fue mayor que para el blanco $(p<0,001)$. En conclusión, no se encontraron diferencias significativas en los niveles de Cr entre los grupos raciales, levantando dudas sobre la utilización del ajuste por la raza en la fórmula para la TFGe en esta población.

Creatinina; Tasa de Filtración Glomerular; Origen Étnico y Salud 


\section{Contributors}

All authors contributed equally in the production of the paper.

\section{Acknowledgments}

We are greatful for the support of the Fundação Municipal de Saúde de Niterói and Fundação de Amparo à Pesquisa do Estado do Rio de Janeiro (FAPERJ).

\section{References}

1. Jha V, Garcia-Garcia G, Iseki K, Li Z, Naicker S, Plattner B, et al. Chronic kidney disease: global dimension and perspectives. Lancet 2013; 382: 260-72.

2. Schieppati A, Remuzzi G. Chronic renal disease as a public health problem: epidemiology, social, and economic implications. Kidney Int Suppl 2005; (98):S7-10.

3. Stevens L, Coresh J, Greene T, Levey AS. Assessing kidney function: measured and estimated glomerular filtration rate. N Engl J Med 2006; 354:2473-83.

4. Levey AS, Bosch JP, Lewis JB, Greene T, Rogers N, Roth D. A more accurate method to estimate glomerular filtration rate from serum creatinine: a new prediction formula. Modification of Diet in Renal Disease Study Group. Ann Intern Med 1999; 130:461-70.

5. Levey AS, Stevens LA, Schmid CH, Zhang YL, Castro 3rd AF, Feldman HI, et al. A new formula to estimate glomerular filtration rate. Ann Intern Med 2009; 150:604-12.

6. Perrone RD, Madias NE, Levey AS. Serum creatinine as an index of renal function: new insights into old concepts. Clin Chem 1992; 38:1933-53.

7. National Kidney Foundation. K/DOQI clinical practice guidelines for chronic kidney disease: evaluation, classification and stratification. Am J Kidney Dis 2002; 39(2 Suppl 1):S1-266.

8. Levey AS, Eckardt KU, Tsukamoto Y, Levin A, Coresh J, Rossert J, et al. Definition and classification of chronic kidney disease: a position statement from Kidney Disease: Improving Global Outcomes (KDIGO). Kidney Int 2005; 67:2089-100.
9. Jones CA, McQuillan GM, Kusek JW, Eberhardt MS, Herman WH, Coresh J, et al. Serum creatinine levels in the US population: third National Health and Nutrition Examination Survey. Am J Kidney Dis 1998; 32:992-9.

10. Gallagher D, Visser M, De Mersman RE, Sepulveda D, Baumgartner RN, Pierson RN, et al. Appendicular skeletal muscle mass: effects of age, gender, and ethnicity. J Appl Physiol 1997; 83:229-39.

11. van Deventer HE, George JA, Paiker JE, Becker PJ, Katz IJ. Estimating glomerular filtration rate in black South Africans by use of the modification of diet in renal disease and Cockcroft-Gault formulas. Clin Chem 2008; 54:1197-202.

12. Eastwood JB, Kerry SM, Plange-Rhule J, Micah FB, Antwi S, Boa FG, et al. Assessment of GFR by four methods in adults in Ashanti, Ghana: the need for an eGFR formula for lean African populations. Nephrol Dial Transplant 2010; 25:2178-87.

13. Pena SD, Di Pietro G, Fuchshuber-Moraes M, Genro JP, Hutz MH, Kehdy S, et al. The genomic ancestry of individuals from different geographical regions of Brazil is more uniform than expected. PLoS One 2011; 6:e17063.

Submitted on $09 /$ Oct/2014

Final version resubmitted on 20/May/2015

Approved on 08/Jun/2015 